\title{
PENGARUH PRAKTIK PENGALAMAN LAPANGAN DAN PRESTASI BELAJAR TERHADAP MINAT MENJADI GURU AKUNTANSI
}

\author{
Wahyu Sholekah \\ wahyusholekah15@gmail.com, Pendidikan Akuntansi, Universitas PGRI Madiun
}

\section{Supri Wahyudi Utomo}

supri@unipma.ac.id, Pendidikan Akuntansi, Universitas PGRI Madiun

Elly Astuti

ellyastuti@ unipma.ac.id, Pendidikan Akuntansi, Universitas PGRI Madiun

\begin{abstract}
Abstrak
Guru adalah kunci dalam sistem pendidikan agar suatu pembelajaran dapat berjalan. Pendidikan Akuntansi merupakan salah satu program studi di Universitas PGRI Madiun yang focus untuk mencetak lulusannya menjadi guru akuntansi professional. Namun demikian berdasarkan hasil observasi awal menujukkan bahwa mahasiswa di lingkup Pendidikan Akuntansi Universitas PGRI Madiun lebih tertarik menjadi pegawai kantoran yang lebih mengarah pada rumpun ilmu akuntansi murni. Untuk itu penelitian ini bertujuan untuk mengetahui lebih jauh pengaruh praktik pengalaman lapangan (PPL) dan prestasi belajar terhadap minat menjadi guru. Teknik pengambilan sampel menggunakan sampel jenuh. Metode analisis data menggunakan regresi linier berganda. Hasil dari penelitian ini menunjukkan bahwa Praktik Pengalaman Lapangan (PPL) berpengaruh positif terhadap minat mahasiswa menjadi guru. Sedangkan prestasi belajar tidak berpengaruh terhadap minat mahasiswa menjadi guru.
\end{abstract}

Kata Kunci : PPL, Prestasi Belajar, Minat

\begin{abstract}
The teacher is the key in the education system so that learning can take place. Accounting education is a PGRI Madiun University study program that focuses on producing graduates to become professional accounting teachers. However, based on the preliminary observations, it shows that students in the scope of Accounting Education at PGRI Madiun University are more interested in becoming office employees who are more directed towards the pure accounting knowledge family. For this reason, this study aims to determine the effect of field experience (PPL) practice and learning achievement on interest in becoming a teacher. The sampling technique uses saturated samples. The data analysis method used multiple linear regression. This study's results indicate that Field Experience Practices (PPL) have a positive effect on student interest in becoming teachers. Meanwhile, learning achievement does not affect students' interest in becoming teachers.
\end{abstract}

Keywords: PPL, Learning Achievement, Interest

\section{PENDAHULUAN}


Salah satu cara untuk meningkatan mutu warga negara dapat dilakukan dengan meningkatkan mutu pendidikan. Mutu pendidikan dapat mencapai standar yang ditetapkan, jika seluruh komponen yang ada didalam sekolah dapat bekerjasama. Salah satu aspek terpenting dalam upaya peningkatan mutu pendidikan adalah guru. Guru adalah kunci utama pelaksana kegiatan belajar dan mengajar.

Untuk menjadi guru professional, salah satunya ditempuh dengan pendidikan formal Srata 1 kejuruan pendidikan, pendidikan profesi guru ataupun pendidikan lanjutan ke Srata 2 bahkan ke Srata 3. Universitas PGRI Madiun merupakan transformasi dari IKIP PGRI Madiun yang dulunya berfokus pada bidang pendidikan untuk mencetak tenaga guru profesional. Setelah menjadi Universitas, bidang pendidikan beralih menjadi wewenang FKIP.

Universitas PGRI Madiun mewajibkan seluruh mahasiswa FKIP melaksanakan program Magang III (PPL). Tujuannya supaya mahasiswa dapat memperoleh pengalaman dalam mengajar peserta didik secara langsung. Pengalaman tersebut memberikan pemahaman lebih dalam mengenai tugas-tugas seorang guru. PPL adalah aktivitas di dalam sekolah yang bertujuan untuk melatih ketrampilan mahasiswa menjadi tenaga pendidik atau guru profesional (Ardyani, 2014). Pengalaman mahasiswa ketika PPL membuat mahasiswa mempunyai keinginan menjadi guru, karena mereka semakin memahami tugas-tugas seorang guru serta menariknya profesi ini (Syofyan et al., 2018). Yuniasari \& Djazari (2017) dan Maipita \& Mutiara (2018) mendokumentasikan bahwa pengalaman PPL juga berpengaruh positif terhadap kesiapan mahasiswa menjadi guru professional.

Namun demikian hasil observasi awal pada Program Studi Pendidikan Akuntansi menunjukkan bahwa tidak semua mahasiswa berminat menjadi guru. Banyak mahasiswa yang memiliki keinginan atau cita-cita bekerja di kantoran meskipun mereka kuliah di jurusan kependidikan. Untuk itu dalam penelitian ini, peneliti juga akan melakukan pengujian prestasi belajar siswa terhadap minat menjadi guru. Sukmawati (2017) menyatakan bahwa prestasi belajar berupa keterampilan dan pengetahuan yang sudah diperoleh dengan melakukan serangkaian proses dalam pembelajaran dan tugas-tugas yang sudah dikerjakan. Mahasiswa yang bersungguh-sungguh melalui semua proses pembelajaran dan mengerjakan tugas dengan baik, diasumsikan karena mereka tertarik dengan ilmu pendidikan yang pada akhirnya menuju karir guru professional.

Mahasiswa yang mempunyai minat terhadap pekerjaan akan menghasilkan pekerjaan yang maksimal dibandingkan dengan yang tidak mempunyai minat, jika mahasiswa mempunyai minat maka akan mencari informasi atau wawasan tentang profesi menjadi guru. Ni'mah \& Oktarina (2014) menyatakan jika prestasi belajar adalah sebuah faktor yang menunjang keberhasilan seorang tenaga pendidik. Ardyani \& Latifah (2014) mendokumentasikan bahwa prestasi belajar mahasiswa pendidikan akuntansi di Universitas Negeri Semarang berpengaruh positif terhadap minat menjadi guru. Untuk itu, penelitian ini akan menggunakan Pengalaman PPL dan prestasi belajar sebagai variable independen yang mempengaruhi minat menjadi guru sebagai variable dependen. 
Beberapa literatur terdahulu menunjukkan bahwa pengalaman PPL dan prestasi belajar berpengaruh positif terhadap minat menjadi guru. Namun demikian hal itu kurang relevan dengan hasil observasi awal peneliti. Kondisi dan budaya teman sebaya mungkin menjadi salah satu alasannya, karena beberapa penelitian terdahulu dilakukan pada PTN, sedangkan penelitian ini dilakukan pada PTS. SBMPTN yang menerapkan seleksi ketat, diasumsikan menjadi saringan tersendiri bagi mahasiswa yang benar-benar berminat menjadi guru professional. Ningrum et al., (2013) memproksikan minat dengan urutan pilihan masuk dalam SBMPTN. Untuk itu penelitian ini berkontribusi untuk memberikan pembuktian apakah pengalaman PPL dan prestasi belajar merupakan faktor-faktor yang mempengaruhi minat menjadi guru mahasiswa di PTS.

\section{TINJAUAN PUSTAKA}

\section{Praktik Pengalaman Lapangan (PPL)}

Yulianto \& Khafid (2016) menyatakan bahwa PPL adalah muara yang dihayati pada saat masa belajar dan terdiri dari semua program pada pendidikan. Praktik Pengalaman Lapangan adalah suatu cara untuk memperkenalkan kepada calon guru tentang dunia profesinya. Diharapkan ketika mahasiswa sudah mengikuti PPL memberikan pengalaman belajar bagi siswa, yang utama dalam pengetahuan mengajar, memperluas wawasan, kemandirian, tanggung jawab dan kemampuan memecahkan masalah. Adapun indikator untuk mengukur variabel praktik pengalaman lapangan yaitu:

1) Keterampilan mengajar

Kemampuan spesifik wajib dimiliki oleh guru ataupun calon guru supaya dapat melakukan tugas mengajar secara efisien, professional dan efektif. Kemampuan ini bersifat mendasar harus dikuasai dalam melakukan kegiatan belajar mengajar.

2) Pengetahuan profesi

Suatu pekerjaan membutuhkan pengetahuan ataupun keterampilan sehingga seseorang tersebut dapat menjalankan profesinya secara memadai

3) Sikap kerja.

Seseorang yang bekerja atau sedang melakukan sesuatu akan optimal jika seseorang tersebut benar-benar senang dengan apa yang dikerjakan. Hal ini didukung oleh rasa nyaman dan kepuasan dalam bekerja. Dari penjelasan diatas bisa disimpulkan Praktik Pengalaman Lapangan (PPL) merupakan kegiatan yang diikuti mahasiwa pendidikan berupa latihan mengajar bersifat akademik ataupun non akademik.

\section{Prestasi Belajar}

Prestasi dalam belajar didapat oleh mahasiswa pada proses belajar mengajar melalui beberapa tes kemampuan, nilai sikap dan keaktifan. Prestasi belajar merupakan hasil kegiatan belajar yang sudah dilaksanakan oleh peserta didik dan dinyatakan dengan bentuk huruf atau angka (Ningrum et al., 2013). Prestasi mahasiswa pada umumnya dilihat melalui indeks prestasi belajar (IPK) yang dimiliki oleh mahasiswa. Hasil prestasi belajar bisa berupa simbol angka atau huruf dan bisa diukur dengan tes yang dijalankan selama masa sekolah. Riyani 
(2012) mengungkapkan faktor yang mempengaruhi prestasi belajar : 1) Proses belajar mengajar, metode, sumber dan mahasiswa; 2) Motivasi, bahan ajar, evaluasi, dan alat; 3) Interaksi mahasiswa lingkungan, materi dan kesehatan; 4) Tujuan dan bakat.

\section{Minat Menjadi Guru}

Minat menjadi guru merupakan perasaan suka atau memberikan perhatian lebih besar pada profesi guru dan menyebabkan ketertarikan untuk bekerja menjadi seorang guru dan akan berusaha untuk meningkatkan kompetensi (Yuniasari \& Djazari, 2017). Minat menjadi guru ialah harapan yang muncul dari diri sendiri akan menjadi guru serta menjalankan kewajiban menjadi guru tanpa adanya paksaan (Maipita \& Mutiara, 2018). Seseorang akan cenderung siap menjadi seorang guru jika memiliki minat yang besar menjadi seorang guru, begitupun sebaliknya. Berdasarkan beberapa definisi tersebut, dapat disimpulkan bahwa ketika seseorang berminat pada profesi guru, maka dia akan mendedikasikan waktu, tenaga pikiran maupun sumber daya ekonominya untuk mencapai profesionalisme karir pendidik.

Menurut Yulianto \& Khafid (2016) indikator mengukur minat menjadi guru adalah sebagai berikut : 1) Pengetahuan dan informasi (seseorang yang mempunyai minat dengan profesi guru, akan berusaha untuk mencari informasi-informasi tentang guru. Informasi yang diperoleh nantinya akan membuat seseorang tersebut tau mengenai dunia keguruan); 2) Perasaan senang dan ketertarikan (seseorang memiliki minat untuk menjadi seorang guru pasti akan merasakan senang tentang hal-hal yang berkaitan dengan guru. Perasaan senang tersebut menimbulkan ketertarikan seseorang akan jadi tenaga pendidik); 3) Perhatian yang lebih besar (seseorang akan memiliki perhatian yang lebih ketika memiliki keinginan atau minat akan sesuatu. Orang yang minat menjadi guru pasti akan lebih perhatian mengenai keguruan dibandingkan hal-hal yang lain); 4) Kemauan dan hasrat (hasrat akan timbul ketika seseorang memiliki keinginan atau minat. Seseorang yang minat menjadi guru pasti akan memiliki kemauan untuk berusaha supaya cita-cita menjadi guru bisa tercapai).

Sedangkan Ni'mah \& Oktarina (2014) dan Syofyan et al., (2020) mengklasifikasikan indikator minat menjadi guru meliputi : 1) Perhatian terhadap profesi guru; 2) Kemauan untuk berprofesi sebagai guru dan; 3) Kebutuhan/motif memilih profesi guru.

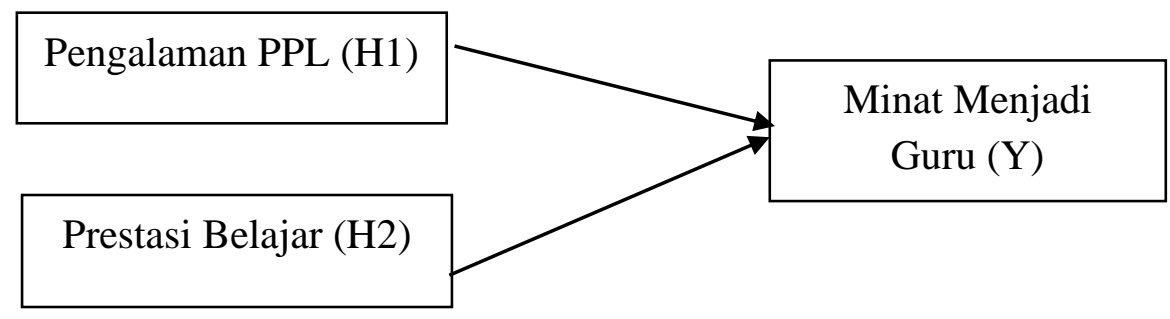

\section{Gambar 1. Kerangka Penelitian}

\section{Pengembangan Hipotesis}


Syofyan et al., (2020) menyatakan bahwa pengalaman mendukung dalam proses pengambilan keputusan pilihan karir. Ketika melaksanakan PPL mahasiswa akan mendapatkan pengalaman mengenai penyusunan RPP, mengajar peserta didik, mengadministrasikan nilai serta melaksanakan tugas-tugas yang berkaitan dengan profesi guru lainnya. Pada saat itu, mahasiswa akan menerapkan teori-teori ilmu kependidikan yang selama ini diperolehnya ketika di kelas dalam praktik riil dilapangan. Pengalaman interaksi dengan lingkungan kerja guru secara riil inilah yang turut mendukung kesiapannya menjadi guru profesional (Yulianto \& Khafid, 2016).

Ketika mahasiswa melaksanakan proses evaluasi atas kegiatan pembelajaran yang dilakukan dan peserta didik mendapatkan nilai yang bagus, tercipta kepuasan dalam diri mahasiswa. Mugiasih et al., (2018) dan Syofyan et al., (2020) mendokumentasikan bahwa ada pengaruh yang positif antara pengalaman PPL terhadap minat mahasiswa menjadi guru.

\section{H1: Pengalaman PPL berpengaruh positif terhadap minat menjadi guru.}

Prestasi belajar tidak bisa dipisahkan dari perbuatan belajar, karena belajar adalah suatu proses, sedangkan prestasi belajar merupakan hasil dari proses pembelajaran tersebut (Thaib, 2013). Prestasi belajar bisa dilihat ketika sudah dilakukan penilaian terhadap hasil belajar siswa. Mahasiswa yang berprestasi akan mempunyai pengetahuan tinggi tentang bagaimana dan apa profesi guru pada kenyataan sebenarnya, sehingga mahasiswa yang punya pengetahuan luas dan bisa menguasai materi pembelajaran akan lebih matang untuk menjadi seorang guru profesional.

Prestasi belajar mahasiswa mengindikasikan kemampuan siswa dalam menyerap ilmu pembelajaran selama kegiatan perkuliahan berlangsung. Kemampuan merupakan salah satu faktor pertimbangan dalam pemilihan karir (Putri et al., 2018). Ketika mahasiswa mampu mendalami ilmu kependidikan dan penerapannya serta pemahaman mengenai dasar keilmuan akuntansi yang memadai, akan medorong mahasiswa untuk mengajarkannya kepada yang lain. Hal ini mendorong mahasiswa untuk memilih profesi menjadi guru akuntasi.

\section{H2: Prestasi belajar berpengaruh positif terhadap minat menjadi guru.}

\section{Metode penelitian}

Penelitian ini termasuk penelitian kuantitatif yang dilakukan di UNIVERSITAS PGRI MADIUN. Sampel yang digunakan ialah mahasiswa pendidikan akuntansi angkatan 2016 sejumlah 96. Teknik pengumpulan data menggunakan metode kuisioner dengan pengisian kuisioner menggunakan skala likert dan dokumentasi yang berasal dari IPK terakhir mahasiswa. Indikator yang digunakan untuk mengukur variabel PPL pada penelitian ini adalah keterampilan mengajar, pengetahuan profesional, dan sikap kerja. Indikator pada variabel prestasi belajar adalah IPK mahasiswa. Sedangkan indikator untuk variabel minat menjadi guru adalah pengetahuan dan informasi, ketertarikan dan perasaan senang, perhatian yang lebih besar, kemauan dan hasrat. Teknik untuk pengambilan sampel menggunakan sampel jenuh, karena menggunakan semua populasi. Teknik analisis data menggunakan bantuan SPSS 25. Metode analisis data yang digunakan adalah uji validitas, uji reabilitas, analisis statistik deskriptif, uji asumsi klasik, analisis regresi berganda, dan menentukan koefisien determinasi. 


\section{Hasil dan pembahasan}

Tabel 1. Uji statistik deskriptif

\begin{tabular}{lccccc}
\hline Variabel & N & Min & Maks & Mean & Std. Deviation \\
\hline $\begin{array}{l}\text { Praktik Pengalaman } \\
\text { Lapangan }\end{array}$ & 96 & 76,01 & 94,44 & 86,6808 & 3,74170 \\
Prestasi Belajar & 96 & 2,89 & 3,93 & 3,4977 & 0,23230 \\
Minat Menjadi Guru & 96 & 26 & 60 & 48,92 & 8,880
\end{tabular}

Berdasarkan Tabel 1 dapat diketahui jika pada penelitian olah data statistik deskriptif memiliki nilai $\mathrm{N}$ dengan jumlah 96. Uji statistik deskriptif menunjukkan nilai min, maksimal, rata-rata (mean) dan standar deviasi. Nilai minimal pada variabel Praktik Pengalaman Lapangan (PPL) sebesar 76,01. Berdasarkan data yang diperoleh, nilai min tersebut diperoleh dari data salah satu mahasiswa yang bernama WE yang dulu pernah melaksanakan kegiatan PPL di SMK CK Kota Madiun. kegiatan PPL di SMK CK Kota Madiun fasilitasnya sudah memadai, akan tetapi ada keterbatasan ruangan seperti basecamp tempat mahasiswa PPL di sekolah tersebut dianggap kurang memadai karena ruangan PPL dijadikan satu dengan ruang kegiatan ekstrakulikuler, hal tersebut membuat mahasiswa kurang nyaman ketika melaksanakan kegiatan PPL di sekolah.

Susilo (2015) berpendapat bahwa fasilitas atau sarana pembelajaran berkondisi baik dan lengkap sesuai kebutuhan sangat mendukung kelancaran dan keterlaksanaan sebuah proses pembelajaran yang efektif dan baik. Jadi bisa disimpulkan bahwa fasilitas dan sarana pada saat melaksanakan kegiatan PPL dapat mempengaruhi minat mahasiswa untuk menjadi guru. Ketika melaksanakan PPL didukung fasilitas yang baik, akan membuat mahasiswa nyaman dan maksimal ketika melaksanakan PPL. Kurangnya wawasan mengenai profesi guru juga akan membuat mahasiswa kurang pengetahuan tentang menjadi guru. selain itu juga karena kurangnya keinginan yang ada dalam diri mahasiswa untuk menjadi seorang guru, jadi mahasiwa lebih menyukai profesi lain seperti akuntan.

Nilai maksimal pada uji statistik PPL sebesar 94,44. adalah mahasiwa yang bernama AN yang melaksanakan kegiatan PPL di MAN XX Kota Madiun. kagiatan belajar mengajar di MAN XX Kota Madiun sangat didukung dengan fasilitas yang memadai. Motivasi dan wawasan dari guru juga sering diberikan untuk mahasiswa dalam melaksanakan kegiatan PPL. Selain itu guru juga sering mengadakan evaluasi kepada mahasiswa PPL dan mengarahkan mahasiswa tentang bagaimana menjalankan profesi guru yang baik. Hal tersebut membuat mahasiswa akan menjalankan kegiatan PPL dengan maksimal, sehingga membuat mahasiswa lebih terdorong untuk menjadi seorang guru selain itu seorang guru adalah pekerjaan yang mulia.

Nilai minimal pada variabel minat menjadi guru adalah sebesar 26. Berdasarkan data yang sudah diperoleh, nilai minimal dilihat dari salah satu mahasiswa yang bernama VN. 
Kurangnya minat untuk menjadi guru bisa disebabkan oleh pengetahuan dan wawasan mengenai seorang guru, akan tetapi bisa juga disebabkan kurangnya motivasi atau dukungan dari orang tua. Mahasiswa akan memiliki minat tinggi untuk menjadi guru jika mempunyai wawasan serta kesiapan belajar yang baik, sehingga menimbulkan kepercayaan diri yang tinggi. Nilai maksimal pada variabel prestasi belajar sebesar 3,93 yang diperoleh berdasarkan IPK terakhir mahasiswa. Nilai maksimal tersebut juga diperoleh mahasiswa yang bernama VN. Kesimpulannya adalah jika mahasiswa memiliki prestasi belajar yang tinggi, belum tentu mahasiswa akan memiliki minat untuk menjadi guru. Mahasiswa yang mempunyai prestasi belajar yang tinggi memiliki keleluasaan untuk memilih profesinya seperti pegawai bank yang diasumsikan dapat memberikan masa depan yang lebih menjanjikan. Nilai minimal pada variabel prestasi belajar adalah sebesar 2,89. Berdasarkan data yang diperoleh, nilai minimal prestasi belajar dilihat dari salah satu data mahasiswa yang bernama DW.

Sedangkan nilai maksimal pada variabel minat menjadi guru adalah sebesar 60 . Berdasarkan data yang diperoleh, ada beberapa mahasiswa yang memiliki nilai maksimal dengan jumlah sama salah satunya adalah DS. Yuniasari \& Djazari (2017) menyatakan bahwa minat menjadi guru merupakan perasaan suka atau memberikan perhatian lebih besar pada profesi guru dan menyebabkan ketertarikan untuk bekerja menjadi seorang guru sehingga berusaha untuk meningkatkan kompetensi. Motivasi yang tinggi juga diperlukan untuk mendukung minat menjadi guru. Minat menjadi guru bisa timbul jika adanya motivasi yang baik, sehingga muncul perasaan senang dan tertarik menjadi guru.

Nilai mean pada Tabel 1 menunjukkan dari ketiga variabel memiliki mean melebihi nilai standar deviasi. Dapat disimpulkan bahwa data memiliki variasi atau perbedaan pada setiap item pertanyaan baik.

Tabel 2. Analisis Regresi Linier Berganda

\begin{tabular}{lccccc}
\hline \multicolumn{1}{c}{ Model } & \multicolumn{2}{c}{$\begin{array}{c}\text { Unstandardized } \\
\text { coefficients }\end{array}$} & $\begin{array}{c}\text { Standardized } \\
\text { coefficients }\end{array}$ & T & Sig. \\
& B & $\begin{array}{c}\text { Std. } \\
\text { Error }\end{array}$ & B & & \\
& & & & & \\
& $-31,554$ & 20,206 & & $-1,562$ & 0,122 \\
(constan) & 1,077 & 0,238 & 0,454 & 4,523 & 0,000 \\
$\begin{array}{l}\text { Praktik pengalaman } \\
\text { lapangan }\end{array}$ & $-3,685$ & 3,836 & $-0,096$ & $-0,961$ & 0,339 \\
Prestasi belajar & & & & & \\
\hline
\end{tabular}

\section{Pengaruh Praktik Pengalaman Lapangan Terhadap Minat Menjadi Guru pada Mahasiswa Pendidikan Akuntansi}

Berdasarkan Tabel 2 diketahui bahwa praktik pengalaman lapangan berpengaruh 
secara signifikan terhadap minat menjadi guru. Hal ini ditunjukkan dengan nilai sig dengan besaran 0,00 lebih sedikit jika dibandingkan dengan nilai alpha $(0,05)$ dan nilai t hitung 4,523 lebih tinggi dari nilai t tabel 1,985. Hasil penelitian ini sejalan Syofyan et al. (2020) dan Ardyani \& Latifah (2014) bahwa praktik pengalaman lapangan berpengaruh positif terhadap minat menjadi guru. Mahasiswa akan memiliki minat tinggi untuk menjadi guru jika mahasiswa mempunyai wawasan yang luas serta kesiapan belajar yang baik, sehingga menimbulkan kepercayaan diri yang tinggi. Melalui kegiatan PPL ini mahasiswa bisa mengenal atau mengetahui bagaimana tugas-tugas guru di dalam sekolah.

Menurut Yulianto \& Khafid (2016) indikator pengukuran variabel PPL meliputi keterampilan mengajar, pengetahuan profesi dan sikap kerja. Mahasiswa yang sudah melaksanakan PPL akan mengetahui bagaimana cara mengajar dengan baik, mengetahui seperti apa seorang guru itu dan bagaimanakah pekerjaan guru yang sesungguhnya. Ketika mahasiswa melakukan kegiatan PPL dengan maksimal, maka akan membuat mahasiswa memiliki minat untuk menjadi guru. Pengalaman pada saat mengikuti PPL akan membuat mahasiswa memiliki wawasan dan pengetahuan tentang dunia kerja. Sehingga membuat mahasiswa mengetahui bagaimana proses mengajar di kelas yang sesungguhnya dan bisa mengetahui bagaimana kegiatan guru pada saat di sekolah. Hal ini membuat mahasiswa memiliki minat tinggi untuk menjadi guru karena mahasiswa sudah mendapatkan pengalaman dan ilmu pada saat mengikuti kegiatan PPL.

Pratik Pengalaman Lapangan yang sudah dilakukan oleh mahasiswa akan menghasilkan keterampilan dan pengalaman nyata mengenai dunia kerja yang sesungguhnya. Mugiasih et al. (2018) juga mendokumentasikan bahwa praktik pengalaman lapangan (PPL) berpengaruh positif signifikan terhadap minat menjadi guru. Penelitian ini menunjukkan jika PPL mempunyai peran yang penting terhadap minat mahasiswa menjadi guru. Semakin banyak pengalaman yang diperoleh mahasiswa ketika PPL, semakin tinggi juga minat mahasiswa menjadi guru.

\section{Pengaruh Prestasi Belajar Terhadap Minat Menjadi Guru pada Mahasiswa Pendidikan Akuntansi}

Tabel 2 menunjukkan bahwa prestasi belajar tidak berpengaruh terhadap minat menjadi guru. Hal ini dibuktikan dengan nilai sig lebih besar dari alpha sebesar 0,339>0,05 dan koefisien bernilai negatif sebesar -0,96. Hasil penelitian ini menunjukkan bahwa tinggi rendahnya prestasi belajar tidak mempengaruhi minat untuk menjadi guru. Hasil penelitian ini menunjukkan kondisi yang berbeda dari penelitian sebelumnya yang dilakukan oleh Yulianto \& Khafid (2016), Putri et al. (2018) dan Ardyani \& Latifah (2014). Perbedaan tersebut kemungkinan terjadi karena beberapa penelitian terdahulu melakukan penelitian pada PTN sehingga mahasiswa yang masuk jurusan tersebut, benar-benar memiliki minat menjadi guru.

Prestasi belajar tidak dapat mempengaruhi pilihan karir mahasiswa pendidikan akuntansi di Universitas PGRI Madiun disebabkan oleh persepsi mereka terhadap profesi guru dan lingkungan teman sebaya. Fadilla et al. (2020) mendokumentasikan bahwa persepsi profesi guru berpengaruh negatif terhadap minat menjadi guru, sedangkan teman sebaya memberikan dampak positif. Sesuai dengan hasil observasi awal pada penelitian ini, 
mahasiswa pendidikan akuntansi di Universitas PGRI Madiun lebih menyukai pekerjaan lainnya seperti pegawai bank ataupun instansi yang berkaitan dengan penerapan ilmu akuntansinya. Hasil wawancara secara informal dengan beberapa responden ketika proses pengisian angket, mahasiswa menyatakan proses menjadi guru memerlukan waktu, tenaga serta biaya yang tidak sedikit. Setidaknya mereka harus melakukan pengabdian dulu di sekolah, mengikuti Pendidikan Profesi Guru (PPG) dan mengerjakan tugas adminsitratif yang cukup menyita waktu.

Riyani (2012) menujukkan bahwa proses belajar mengajar, interaksi mahasiswa dengan mahasiswa lainnya, serta minta dan lingkungan belajar memberikan dampak positif terhadap prestasi belajar. Sehingga dapat disimpulkan bahwa prestasi belajar mahasiswa yang tinggi bukan disebabkan oleh minat dan dorongan untuk menentukan pilihan karir berprofesi menjadi guru, namun lebih pada situasi dan lingkungan di prodi Pendidikan Akuntansi Universitas PGRI Madiun lah yang membuat prestasi mahasiswa tinggi. Mereka lebih terfokus untuk menguasai bidang ilmu akuntansi dengan tujuan pilihan karir pada profesi lain seperti akuntan dan tidak mengarah kepada profesi keguruan ataupun bidang pekerjaan yang berkaitan erat dengan keuangan.

\section{SIMPULAN}

Praktik pengalaman lapangan (PPL) berpengaruh positif terhadap minat menjadi guru. Melalui kegiatan PPL ini mahasiswa bisa mengenal atau mengetahui bagaimana tugas-tugas guru di dalam sekolah. Prestasi belajar tidak mempengaruhi minat menjadi guru karena kompetensi yang dimiliki lebih terarah pada keprofesian lain seperti akuntan dan tidak mengarah kepada profesi keguruan. Hal tersebut dapat didasari oleh beberapa faktor seperti lingkungan teman sebaya, persepsi individu terhadap profesi guru, motivasi, sikap dan minat.

Penelitian ini memiliki keterbatasan yaitu tidak bisa bertatap langsung dengan beberapa responden ketika proses pengisian kuisioner karena adanya aturan PSBB sehingga kuisioner penelitian hanya bisa dilakukan secara online dengan mengirim google form. Penelitian selanjutnya diharapkan bisa menambah variabel bebas atau mengganti variabel bebas, seperti kecerdasan emosional, lingkungan keluarga atau lingkungan masyarakat.

\section{DAFTAR PUSTAKA}

Ardyani, A., \& Latifah, L. (2014). Analisis Faktor-Faktor Yang Mempengaruhi Minat Mahasiswa Menjadi Guru Akuntansi Pada Mahasiswa Prodi Pendidikan Akuntansi Angkatan 2010 Universitas Negeri Semarang. Economic Education Analysis Journal, 3(2), 232-240.

Fadilla, S. A., Sawiji, H., \& Murwaningsih, T. (2020). Pengaruh Persepsi Profesi Guru dan Teman Sebaya Terhadap Minat Menjadi Guru pada Mahasiswa Pendidikan Administrasi Perkantoran FKIP UNS. Jurnal Informasi Dan Komunikasi Administrasi Perkantoran, 4(2), 51-64.

Maipita, I., \& Mutiara, T. (2018). Pengaruh Minat Menjadi Guru dan Praktik Program Pengalaman Lapangan (PPL) Terhadap Kesiapan Menjadi Guru pada Mahasiswa Jurusan Ekonomi Universitas Negeri Medan. Jurnal Ekonomi Pendidikan, 8(6), 34-43. https://jurnal.unimed.ac.id/2012/index.php/ekodik/article/view/10777

Mugiasih, N. M., Sudarsana, I. B. O., \& Alit, D. M. (2018). Pengaruh Kesiapan Mengajar dan 
Praktik Pengalaman Lapangan ( PPL ) Terhadap Minat Menjadi Guru Mahasiswa Program Studi Pendidikan Ekonomi FPIPS IKIP PGRI Bali Angkatan Tahun 2014. Social Studies, 6(2), 6-10. https://ojs.ikippgribali.ac.id/index.php/socialstudies/article/download/537/421

Ni'mah, F. U., \& Oktarina, N. (2014). Pengaruh Minat Profesi Guru, Locus of Control Internal, Peran Guru Pamong Dan Prestasi Belajar Terhadap Kesiapan Mahasiswa Menjadi Guru Pada Jurusan Pendidikan Ekonomi Fakultas Ekonomi Universitas Negeri Semarang. Economic Education Analysis Journal, 3(2), 336-342.

Ningrum, P. K., Susilaningsih, \& Sumaryati, S. (2013). Hubungan Antara Minat Menjadi Guru Dan Lingkungan Keluarga Dengan Prestasi Belajar. Jupe UNS, 2(1), 59-71. https:://www.jurnal.fkip.uns.ac.id/index.php/ekonomi/article/view/2697

Putri, D. A., Harini, \& Nugroho, J. A. (2018). Pengaruh Persepsi Mahasiswa Tentang Kesejahteraan Guru dan Prestasi BelajarTerhadap Minat Menjadi Guru Ekonomi Pada Mahasiswa Program Studi Pendidikan Ekonomi FKIP UNS. BISE: Jurnal Pendidikan Bisnis Dan Ekonomi, 4(1), 85-98.

Riyani, Y. (2012). Faktor-Faktor Ekstern Yang Mempengaruhi Prestasi Belajar Mahasiswa (Studi pada mahasiswa Jurusan Akuntansi Politeknik Negeri Pontianak). Edunomic Jurnal Pendidikan Ekonomi, 8(1), 19-25. https://doi.org/10.33603/ejpe.v5i2.246

Sukmawati, D. (2017). Pengaruh Prestasi Belajar, Dukungan Sosial Keluarga Dan Teman Sebaya Terhadap Literasi Keuangan Siswa. Jurnal Ekonomi Pendidikan Dan Kewirausaan, 4(1), 30-41.

Susilo, H. A. (2015). Pengaruh Fasilitas Belajar Terhadap Kepuasan Siswa pada SMK Satrya Budi Karang Rejo. Jurnal MAKER, 1(1), 14-21.

Syofyan, R., Hidayati, N. S., \& Rahmi, E. (2020). Pengaruh Program Pengalaman Lapangan Kependidikan (PLK) dan Efikasi Diri terhadap Minat Menjadi Guru. Jurnal Inovasi Pendidikan Ekonomi, 10(2), 151-162. Jurnal Inovasi Pendidikan Ekonomi Available at h

Thaib, E. N. (2013). Hubungan Antara Prestasi Belajar Dengan Kecerdasan Emosional. Jurnal Ilmiah Didaktika, 13(2), 384-399. https://doi.org/10.22373/jid.v13i2.485

Yulianto, A., \& Khafid, M. (2016). Pengaruh Praktik Pengalaman Lapangan (PPL), Minat Menjadi Guru, Dan Prestasi Belajar Terhadap Kesiapan Mahasiswa Menjadi Guru Yang Profesional. Economic Education Analysis Journal, 5(1), 100-114.

Yuniasari, T., \& Djazari, M. (2017). Pengaruh Minat Menjadi Guru, Lingkungan Keluarga, Dan Praktik Pengalaman Lapangan (PPL) Terhadap Kesiapan Menjadi Guru Akuntansi Mahasiswa Pendidikan Akuntansi Angkatan 2013 FE UNY. Jurnal Pendidikan Akuntansi Indonesia, 15(2), 78-91. https://doi.org/10.21831/jpai.v15i2.17220 